\title{
THE STAFF-TREE, CELASTRUS SCANDENS, AS A FORMER FOOD SUPPLY OF STARVING INDIANS
}

\section{FRANK T. DILLINGHAM}

IN many kinds of hard and horny seeds there is present, as a reserve material, a carbohydrate which upon hydrolysis yields mannose (a simple sugar closely related to glucose). This carbohydrate has been named mannan. It is one of the hemi-celluloses, a group of substances closely resembling in appearance the true celluloses, but easily resolved into simpler carbohydrates by the hydrolytic action of enzymes or of dilute acids. There is no lack of evidence that mannan which occurs abundantly in the so-called vegetable ivory, Phytelephas macrocarpa, and in the seeds of many other palms, as well as in the wood of coniferous trees, is in spite of its hardness, fit food for camels, neat cattle, sheep, and various rodents. This is illustrated in the girdling of pine trees by mice, as recorded by Thoreau in "Walden." ${ }^{1} \mathrm{He}$ says:- "There were scores of pitch-pines around my house, from one to four inches in diameter, which had been gnawed by mice the previous winter,- a Norwegian winter for them, for the snow lay long and deep, and they were obliged to mix a large proportion of pine bark with their other diet. These trees were alive and apparently flourishing at mid-summer, and many of them had grown a foot, though completely girdled; but after another winter such were without exception dead. It is remarkable that a single mouse should thus be allowed a whole pine tree for its dinner, gnawing round instead of up and down it; but perhaps it is necessary in order to thin these trees, which are wont to grow up densely."

It is known that the root of a Japanese plant, Conophallus konnjaku, rich in mannan is used as human food, and the question may fairly be asked whether the former use of bark bread by the inhabitants of Scandinavia might not have been dependent upon the mannan in the bark. After discussing this matter in the

${ }^{1}$ Walden, p. $300 . \quad$ Jas. R. Osgood \& Co. Boston, 1876. 
Bulletin of the Bussey Institution (1906, Vol. 3, pp. 120-128), the writer learned that some tribes of North American Indians in times of extreme dearth were accustomed to keep body and soul together by boiling and eating the bark of the Staff-tree, Celastrus scandens. The Staff-tree is also called the staff-vine; false, climbing or shrubby bittersweet; wax-work, fever-twig, yellowroot, climbing orange-root and Jacob's ladder.

Radisson, wintering near the outlet of Lake Superior about the year 1658, found the Indians suffering greatly from starvation He writes: ${ }^{1}$ - "Those that have any life seeketh out for roots, which could not be done without great difficulty, the earth being frozen 2 or 3 feet deep, and the snow 5 or 6 above it. The greatest subsistence that we can have is of rind tree which grows like ivy about the trees; but to swallow it, we cut the stick some 2 foot long, tying it in fagot, and boil it, and when it boils one hour or two the rind or skin comes off with ease, we take and dry it in the smoke and then reduce it into powder betwixt two grain stones, and putting the kettle with the same water upon the fire, we make it a kind of broth which nourishes us, but become thirstier and drier than the wood we ate."

In the Report of the U. S. Commissioner of Agriculture for 1870, (p. 422), there is the following statement:- "The Chippewa Indians use as food the tender branches of the Staff tree (Celastrus scandens). This climbing shrub, the bois retors of the French, or twisted wood, is sometimes called bitter sweet. It has a thick bark and is sweetish and palatable when boiled."

In view of the above statements, specimens of both the bark and the wood of the Staff-tree were tested for mannan. On the grounds of the Bussey Institution, on Jan. 24th, 1907, branches of the Staff-tree were cut in pieces about one foot in length. Both the inner and outer bark were removed together, no attempt being made to separate them. The outer bark was thin, but the inner bark was thick and fleshy. The material was carefully dried, ground to a fine meal, and a weighed quantity of it was boiled with dilute hydrochloric acid for three hours. A small portion of the liquor thus obtained was neutralized with sodium hydroxide and examined for mannose by the addition of a few

${ }^{1}$ Voyages of P. E. Radisson, p. 204, Prince Society Edition, Boston, 1885. 
drops of phenylhydrazine acetate. No mannose hydrazone crystals formed at this point. The remainder of the liquor, after being similarly neutralized, was evaporated to dryness; the residue was treated with a small quantity of water; and the concentrated liquor thus obtained was tested for mannose by adding a few drops of phenylhydrazine acetate. With the aid of the microscope, the formation of characteristic crystals of mannose hydrazone was observed. ${ }^{1}$ The wood proper (including the pith) was reduced to a fine meal and then treated in precisely the same manner as was the bark.

From these tests it appears that unlike the bark of most deciduous trees, that of the Staff-tree contains an abundance of mannan. The bark of the Staff-tree, moreover, contains a larger quantity of mannan than does the wood proper.

To confirm Radisson's statement as to the effect of boiling, a few branches of the Staff-tree were boiled with water for about one hour. At the end of this time the bark was found to peel off with great ease. It was seen to be thick, pulpy, and very mucilaginous, and it had a rather agreeable taste.

It is evident from these experiments that a part, at least, of the physiological value of the bark of the Staff-tree may be justly attributed to the presence of mannan.

Bussey Institution of Harvard University Jamaica Plain, Mass.

${ }^{1}$ This method has been explained in detail in the Bulletin of the Bussey Institution. 1902, 3, p. 30. 1903, 3, p. 47. 